\title{
Antibodies against Sulphoquinovosyl-diacyl glycerol and their Reactions with Chloroplasts
}

\author{
Alfons Radunz and Richard Berzborn* \\ Max-Planck-Institut für Züchtungsforschung (Erwin Baur-Institut), Abteilung Menke, \\ 5 Köln-Vogelsang, Germany ** \\ (Z. Naturforsch. 25 b, 412-419 [1970] ; eingegangen am 20. November 1969)
}

\begin{abstract}
Using immunological techniques we tried to determine the localization and orientation of the sulpholipid of chloroplasts in thylakoids. During immunization of rabbits with lamellar systems of chloroplast's of Antirrhinum majus antisera were obtained which precipitated sulpholipid emulsions. Antibodies against the sulpholipid were not detected until a second series of intravenous injections.

By immunizing purified sulpholipid of Fucus serratus, adsorbed to methylated bovine serum albumin, sulpholipid antisera were acquired. These antisera and the antisera against lamellar systems of Antirrhinum majus reacted with preparations of sulpholipid from widely different plant species. The sulpholipid antisera did not react with emulsions of the mono- or digalactosyl-diacyl glycerol, of lecithin or the anionic phosphatide phosphatidyl glycerol. Lamellar systems isolated without osmotic shock on a sucrose gradient were not agglutinated by sulpholipid antisera directly, but an indirect agglutination could be achieved in a $\mathrm{C}$ o o m b s-test or in a mixed antigen agglutination after U h le $\mathrm{n} \mathrm{b} \mathrm{r} \mathrm{u} \mathrm{c} \mathrm{k.} \mathrm{Broken} \mathrm{chloroplasts,} \mathrm{however,} \mathrm{were} \mathrm{agglutinated} \mathrm{directly} \mathrm{by} \mathrm{sulpho-}$ lipid antisera, as well lamellar systems which had been disrupted in a French-press or by ultrasonic treatment.

From agglutination and agglutination inhibition experiments with lamellar systems prepared by different methods it is concluded that the determinant groups of the sulpholipid are accessible for antibodies in the lamellar system of chloroplasts. But probably the sulpholipid molecules are located inside the thylakoids.
\end{abstract}

Abbreviations: Sulpholipid $=$ Sulphoquinovosyl-diacyl glycerol $=6$-sulpho- 6 deoxy- $\alpha$-D-glucopyranosyl diglyceride, Tris buffer $=$ Tri (hydroxymethyl) -aminomethane HCl buffer, $\mathrm{EDTA}=$ Ethylenediamine tetra-acetic acid, $\mathrm{NADP}^{\oplus}$ $=$ Nicotinamide adenine dinucleotide phosphate, oxidized form, $\mathrm{BSA}=$ bovine serum albumin, saline $=0.85 \%$ aqueous solution of $\mathrm{NaCl}$.

Earlier investigations with antisera against preparations of ferredoxin-NADP ${ }^{\oplus}$ reductase $^{1-3}$ and preparations of solubilized lamellar structural protein of chloroplasts ${ }^{4,5}$ have shown that it is possible to localize these components at that surface of the lamellar system which is accessible for antibodies. By immunizing rabbits with isolated lamellar systems antisera were obtained which agglutinated emultions of ether soluble lipids of chloroplasts. Using these antisera it has been attempted to localize the lipids in the thylakoid membrane ${ }^{4}$.

In this publication it is shown that these antisera contained antibodies against the sulpholipid of chloroplasts. Therefore a localization of the sulpho-

* Present address: Section of Biochemistry and Molecular Biology, Cornell University, Ithaca, N.Y., USA.

* Preliminary experiments for this publication were carried out in the Institut of Botany at the University of Köln, Germany.

1 R. Berzborn, W. Menke, A. Trebst, and E. Pistorius, Z. Naturforsch. 12 b, 1057 [1966]. lipid and an investigation about the orientation of this lipid in the thylakoid membran appears possible with antigen-antibody reactions. For this purpose it was very useful to get antibodies against the sulpholipid by immunizing with the sulpholipid itself.

\section{Methods and Experiments}

\section{Isolation of lipids}

To obtain the sulphoquinovosyl-diacyl glycerol from plant material the ether soluble lipids were separated chromatographically on columns of $\mathrm{SiO}_{2}$ (Mallinckrodt, 100 mesh, Roth, Karlsruhe, Germany), Diethyl aminoethyl cellulose MN 2100 DEAE, Macherey, Nagel \& Co, Düren, Germany) and florisil (60-100 mesh, Roth, Karlsruhe, Germany). The preparation, identification and fatty acid composition of the different sulpholipids have already been described ${ }^{6}$. After two dimensional thin-layer chromatography of the isolated sulpholipid fractions on Silicagel $\mathrm{G}$ plates in different solvents

2 R. Berzborn, Z. Naturforsch. 23 b, 1096 [1968].

3 R. Berzborn, Z. Naturforsch. 24 b, 436 [1969].

4 R. Berzborn, Dissertation, Köln 1967.

5 R. Berzborn and W. Menke, Z. Naturforsch., im preparation. 
and after spraying with different reagents, only one spot appeared ${ }^{6}$.

Mono- and digalactosyl-diacyl glycerol were also separated out of the ether soluble lipids of Fucus serratus and Antirrhinum majus by column chromatography on the same adsorbents. The galactose of both lipids was identified by thin-layer- and gas chromatography ${ }^{7}$.

Phosphatidyl glycerol was isolated out of the ether soluble lipids of Rhodopseudomonas spheroides on DEAE cellulose columns and was purified on $\mathrm{SiO}_{2}$ columns after ROTSCH and DEBUCH ${ }^{8}$. Lecithin was prepared from the commercially available egg lecithin (Merck, Darmstadt, Germany). Further purification was obtained with DEAE cellulose and $\mathrm{SiO}_{2}$ column chromatography.

\section{Immunization with lamellar systems}

Rabbits were immunized by a series of intravenous injections with lamellar systems isolated out of Antirrhinum chloroplasts in sucrose solutions ${ }^{4,5}$. Five months after completion of the first series the animals received a second series of intravenous injections, five months after completion of this series they got a third series, some animals even got a fourth one. Instead of the first series some animals were immunized with a mixture of lamellar systems and F r e u n d's Adjuvant (compl., Difco No. 0638-60, Difco Lab., Detroit, Michigan, USA) and boostered after 6 weeks ${ }^{4}$. These animals later received series of intravenous injections according to the same schedule than the other rabbits (Fig. 1).

\section{Immunization with sulpholipid adsorbed to methylated $B S A$}

Commercially available BSA (fraction V, Calbiochem, Los Angeles, California, USA) was dissolved in methanol and methylated with $\mathrm{HCl}^{\mathbf{9}}$. The methylated albumin was spun down and washed twice with methanol, twice with ether, and then dried in vacuo over $\mathrm{P}_{2} \mathrm{O}_{5}$. According to the method of INOUE and NoJIMA 10 , * $30 \mathrm{mg}$ sulpholipid and $30 \mathrm{mg}$ lecithin, in a second experiment $3 \mathrm{mg}$ sulpholipid and $30 \mathrm{mg}$ lecithin, and in a third experiment only $30 \mathrm{mg}$ sulpholipid were dissolved in $5 \mathrm{ml}$ ethanol, mixed with $5 \mathrm{ml}$ saline $(0.85 \%$ $\mathrm{NaCl}$ in $\mathrm{H}_{2} \mathrm{O}$ ) and thoroughly shaken by hand in a $50 \mathrm{ml}$ round bottom flask for 2 to $5 \mathrm{~min}$. All the ethanol was evaporated in vacuo to about one third of the volume, distilled water was added to a final volume of $5 \mathrm{ml}$ and $5 \mathrm{ml}$ of an aqueous solution of $0.1 \%(\mathrm{~W} / \mathrm{V})$ methylated BSA was added and again thoroughly

6 A. Radunz, Hoppe-Seyler's Z. physiol. Chem. 350, 411 [1969].

7 A. Radunz, Hoppe-Seyler's Z. physiol. Chem. 349, 303 [1968].

8 E. Rotsch and H. Debuch, Hoppe-Seyler's Z. physiol. Chem. 343, 135 [1965].

9 N. Sucoka and T. Y. Cheng, J. molecular Biol. 4, 161 [1962]. shaken. The suspensions were prepared $12 \mathrm{~h}$ before the injections and kept at $4^{\circ}$. In each experiment 5 rabbits were given 14 intravenous injections of $2 \mathrm{ml}$ of the preparations every other day (Table 1). Lecithin was adsorbed to methylated BSA after the same method as sulpholipid, methylated BSA was injected in saline. In both cases two rabbits were immunized with these antigen for control experiments (Table 1).

\section{Methods to demonstrate antibodies against sulpholipid}

a) Agglutination on slides (slide test): Isolated lamellar systems were suspended in saline, $0.066 \mathrm{M}$ phosphate buffer $\left(\mathrm{KH}_{2} \mathrm{PO}_{4}+\mathrm{Na}_{2} \mathrm{HPO}_{4}\right) \quad(\mathrm{pH}$ 7.4) or $0.02 \mathrm{M}$ Tris buffer ( $\mathrm{pH} 7.4)$ to give a final concentration of $1.5 \mathrm{mg}$ chloroplasts (dry weight) $/ \mathrm{ml}$. Sulpho. lipid and the other lipid fractions were suspended also in saline, or the same buffer, to give a final concentration of $3 \mathrm{mg}$ lipid $/ \mathrm{ml}$ aqueous solution. The suspension was then emulsified by ultrasonic treatment 2 times for 30 sec. in an icebath (MCE Ultrasonic Power Unit, 2.0 Amp.). Because the lipids aggregated a modified latex tests after SINGER and PLOTZ ${ }^{11}$ and after WIEDERMANN ${ }^{12}$ were also carried out. Assuming the density of the lipids to be 1 the amount of lipid was calculated $^{4}$, to give a bimolecular lipid layer on the surface of the latex particles. $50 \mu \mathrm{g}$ lipid were emulsified in $1 \mathrm{ml}$ saline with a suspension of $0.2 \%(\mathrm{~V} / \mathrm{V})$ latex particles with a diameter of $0.79 \mu$ (Polystyrene Latex, The Dow Chemical Comp., Midland, USA). Equal volumes of these preparations and of the sera under investigation were mixed on the slide, the slide gently moved for some seconds and the reaction observed in the microscope.

b) Agglutination in tubes (micro tube test) : $0.04 \mathrm{ml}$ of the antigen suspension and $0.04 \mathrm{ml}$ of a serum in question were mixed in small round bottom glas tubes (4 $\mathrm{mm}$ diameter). The reaction mixture was incubated for $2 \mathrm{~h}$ at $20^{\circ}$ and $16 \mathrm{~h}$ at $4^{\circ}$. During this time all particles settled down and the supernatants became clear. But the small pellets showed characteristic patterns. Similar to the patterns which developed, when agglutinating antibodies reacted with lamellar systems ${ }^{4}$, latex particles with the sulpholipid showed after a reaction with sulpholipid antibodies coarse pellets with notched folded rims or less coarse pellets with minute folded rims depending on the amount of antibodies in the mixture. Standard serum led to homogeneous pellets with smooth rims in adequate mixtures.

c) Determination of the titer: The amount of the antibodies in the antisera could only be determinated

10 K. Inoue and S. Nojima, Biochim. biophysica Acta [Amsterdam] 144, 409 [1967].

* Lipid were adsorbed on methylated BSA. In the first experiment.

11 J. M. Singer and C. M. Plotz, Americ. J. Med. 21, 888 [1956].

12 G. Wiedermann, Zbl. Bakt., Abt. I Orig., Sonderheft 278 [1963]. 
semiquantitatively by analyzing the titer of the agglutination. To determine agglutinating antibodies against lamellar systems 0.04 saline were put in 15 small test tubes (4 mm diameter) $0.04 \mathrm{ml}$ serum added to the first one, mixed and $0.04 \mathrm{ml}$ of the diluted serum transferred to the next tube etc. to make geometric progression with a dilution factor of 0.5 (or $1: 2$ ). To each tube of this dilution series $0.04 \mathrm{ml}$ of a suspension with lamellar systems $(1.5 \mathrm{mg} / \mathrm{ml}$ in saline) was added. After $2 \mathrm{~h}$ at $20^{\circ}$ and $16 \mathrm{~h}$ at $4^{\circ}$ the reaction was judged after the patterns of the pellets ${ }^{4}$.

To determine the antibodies against sulpholipid $0.12 \mathrm{ml}$ serum was added to the first tube with $0.04 \mathrm{ml}$ saline, mixed and $0.12 \mathrm{ml}$ of the diluted serum transferred to the second tube with $0.04 \mathrm{ml}$ saline etc. to make a geometric progression with a dilution factor of 0.75 (or $3: 4$ ). $0.04 \mathrm{ml}$ of a sulpholipid emulsion ( $1 \mathrm{mg} / \mathrm{ml}$ in saline) was added to each tube and mixed. After $2 \mathrm{~h}$ at $20^{\circ}$ the reaction was judged by observing droplets of the mixture in the microscope. To be sure whether a reaction was positive or negative, equal dilution series were made in every case with standard serum.

\section{Experiments to agglutinate lamellar systems indirectly by sulpholipid antisera}

a) Mixed antigen agglutination after UHLENBRUCK ${ }^{13}$ : $0.04 \mathrm{ml}$ of a suspension of lamellar systems $(1.5 \mathrm{mg} / \mathrm{ml}$ in saline), which were isolated in sucrose solutions was mixed on slides with $0.04 \mathrm{ml}$ sulpholipid antiserum and gently agitated for $30 \mathrm{sec}$ or more. Then $0.04 \mathrm{ml}$ of a sulpholipid emulsion after ultrasonic treatment $(3 \mathrm{mg} / \mathrm{ml}$ in saline $)$ was added, and the slides with the droplet gently moved again. The first and the second step of the reaction was examined in the microscope (Table 3 ).

b) Coom bs-Test ${ }^{14}$ : The first step of this reaction is the same as described above. In the second step $0.04 \mathrm{ml}$ of an antiserum against rabbit- $\gamma$-globulin was added (Difco No. 2366-50, Difco Lab Detroit, Michigan, USA). In both cases control experiments were carried out with standard sera, antisera against methylated BSA and saline (Table 3 ).

c) Washing experiment: To remove all antibodies not bound to the surface of the thylakoids in the first step of the mixed antigen agglutination, $0.2 \mathrm{ml}$ of sulpholipid antiserum and $0.2 \mathrm{ml}$ of a suspension of lamellar systems $(1.5 \mathrm{mg} / \mathrm{ml}$ in saline $)$ were mixed in centrifuge tubes. After $2 \mathrm{~h}$ at $20^{\circ}$, and in a second experiment after an additional $16 \mathrm{~h}$ at $4^{\circ}$, the lamellar svstems were spun down for $10 \mathrm{~min}$ at $2000 \mathrm{~g}$ and $4^{\circ}$. The pellet was washed twice in $5 \mathrm{ml} 0.85 \% \mathrm{NaCl}$ solution and spun down. Finally the incubated lamellar systems were suspended in $0.2 \mathrm{ml} 0.066 \mathrm{M}$ phosphate

13 O. Prokop and G. Uhlenbruck, in: Lehrbuch der menschl. Blut- und Serumgruppen II, Edition, VEB Thieme, Leipzig 1966; G. UhlenBruCK and O. Prokop, Dtsch. med. Wschr. 92. 940 [1967]; G. Uhlenbruck, Med. Welt 17, 906 [1965]. buffer $(\mathrm{pH}$ 7.4) and droplets of this preparation was mixed on slides with the sulpholipid emulsion or with the antiserum against rabbit- $\gamma$-globulin, as described above.

\section{Results}

\section{Antibodies against sulpholipid in antisera against lamellar systems of chloroplasts}

When rabbits were immunized with isolated lamellar systems of chloroplasts of Antirrhinum majus by one or more series of intravenous injections *, or by help of F r e u n d's Adjuvant **, antisera were obtained which reacted with several different preparations of soluble and insoluble components of chloroplasts ${ }^{1,4,5}$. Some of the antisera even agglutinated emulsions of ether soluble lipids of chloroplasts.

To clarify the question to which lipid of the chloroplasts the rabbits make antibodies against, when injected with lamellar systems, monogalactosyl-diacyl glycerol, digalactosyl-diacyl glycerol, sulphoquinovosyl-diacyl glycerol and phosphatidyl glycerol out of the chloroplasts were separated chromatographically on columns of $\mathrm{SiO}_{2}$ diethylamino ethyl cellulose and florisil ${ }^{6,7}$. Only the chromatographically pure sulpholipid was agglutinated by the antisera against lamellar systems.

During and after the series of injections the appearance of antibodies against lamellar systems and sulpholipid in the blood serum was observed by estimating the titer of agglutination semiquantitatively. Two rabbits synthesized sulpholipid antibodies during the second series of intravenous injections and two other rabbits during the third series. No difference was found in the appearance of sulpholipid antibodies when the rabbits got an injection of a mixture of lamellar systems with Freund's Adjuvant and two booster injections after 6 weeks instead of a first series of intravenous injections during 2 months.

Fig. 1 shows the titer of the sera of one rabbit. After the second series of injections the antisera agglutinated a sulpholipid emulsion $(0.1 \%$ in saline) down to a dilution of $1: 3$. The titer of

14 R. R. A. Coombs, M. H. Gleeson-White, and J. G. Hall, Brit. J. exp. Pathol. 32, 195 [1951].

* We thank Dr. G. Uhlenbruck for his advice for this immunization schedule.

* We thank Dr. K. RAJEwSKY for his advice for this immunization schedule. 


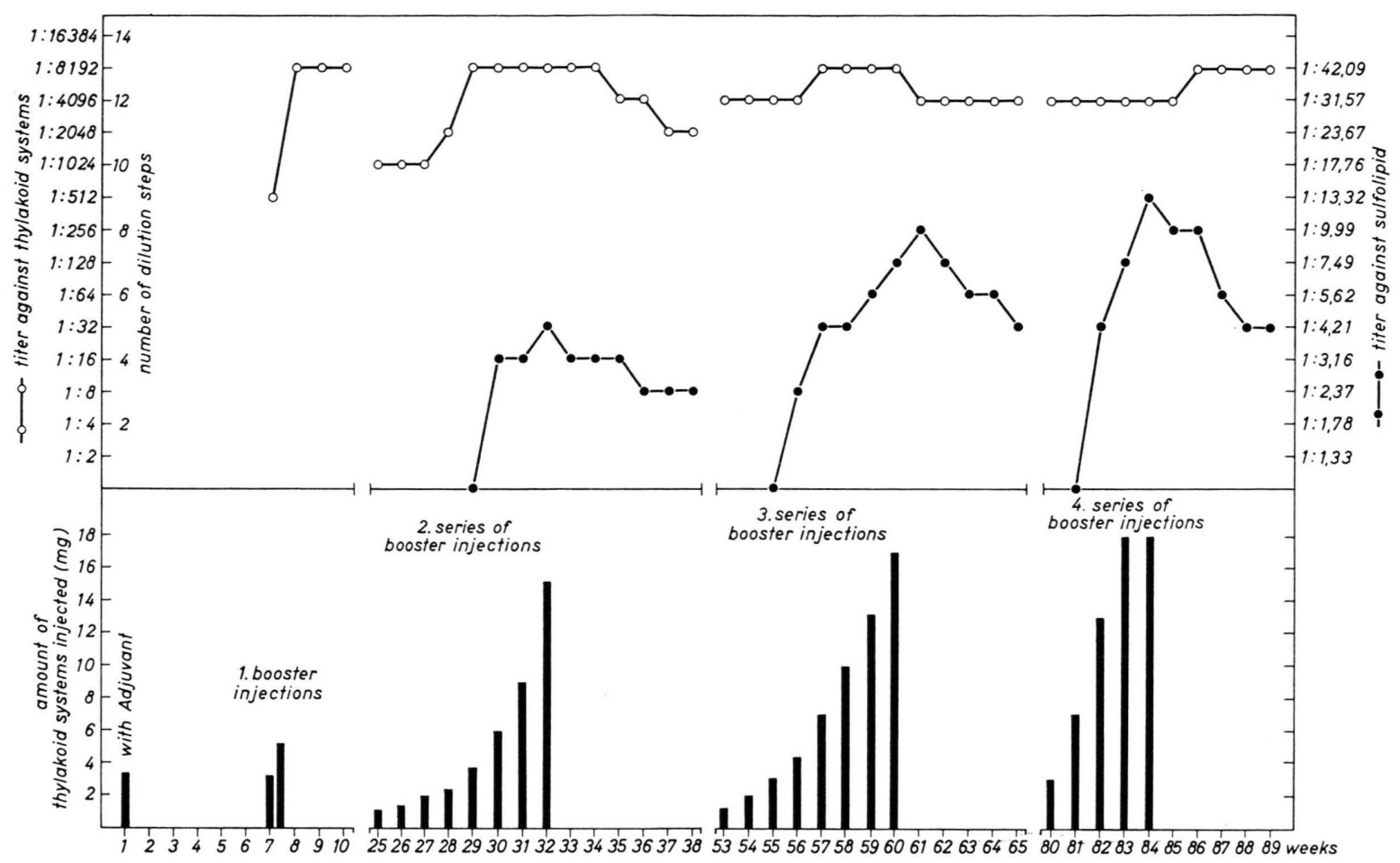

Fig. 1. Titer of agglutinating antibodies in the serum of one rabbit during four series of immunization with isolated lamellar systems of chloroplasts.

antibodies against sulpholipid could be increased by a third and a fourth series of intravenous injections of lamellar systems. At the end of the third series the sera gave a clear positive reaction down to a dilution of $1: 10$ and after the fourth series down to a dilution of $1: 14$.

\section{Antisera against sulpholipid and their characterization}

For the purpose of immunization the sulpholipid was purified from the ether soluble lipids of Fucus serratus $^{6}$. Rabbits were injected every other day with sulpholipid adsorbed to methylated bovine serum albumin (BSA) after INOUE and Nojima ${ }^{10}$. The precise immunization schedule is given under experiments and in Table 1 . After 12 injections the blood serum of each animal contained antibodies against sulpholipd. INOUE and NoJima found that antibodies against cardiolipin are only synthesized when the cardiolipin was absorbed to methylated BSA together with lecithin. To obtain antibodies against sulpholipid this was not necessary. Antisera obtained by injections of sulpholipid adsorbed to methylated BSA reacted with sulpholipid emulsion $(0.1 \%$ in saline) down to a dilution of $1: 10$ as well as antisera which were obtained by injection of sulpholipid absorbed together with lecithin to methylated BSA. The amount of antibodies in the sera could not be increased by further injections. The titer of the antisera, however, was dependent on the amount of sulpholipid injected to each animal. When the rabbits were injected with $0.6 \mathrm{mg}$ instead of $6 \mathrm{mg}$ sulpholipid every other day, the antisera reacted only until a dilution of $1: 3$.

The sulpholipid antisera obtained by immunization with the sulpholipid of the brown alga Fucus serratus also reacted to the same extent with the sulpholipids isolated by the same procedure out of the higher plant Antirrhinum majus, the fern Dryopteris filix-mas, the red alga Batrachospermum monoliforme, the blue-green alga Oscillatoria chalybea and the purple bacterium Rhodopseudomonas spheroides, although there were remarkable differences in the quality and quantity of the fatty acids of the sulpholipids of these organisms ${ }^{6}$. Hydrogenized sulpholipid emulsions reacted with the antisera, but 


\begin{tabular}{|c|c|c|c|}
\hline $\begin{array}{l}\text { Composition and amount of the } \\
\text { antigens for each injection }\end{array}$ & $\begin{array}{l}\text { number and kind } \\
\text { of injection }\end{array}$ & $\begin{array}{l}\text { number of animals with } \\
\text { antibodies against } \\
\text { sulpholipid/number of } \\
\text { treated animals }\end{array}$ & $\begin{array}{l}\text { titer against } \\
\text { sulpholipid }\end{array}$ \\
\hline $\begin{array}{l}\text { 1. } 6 \mathrm{mg} \text { sulpholipid and } 6 \mathrm{mg} \\
\text { lecithin in } 2 \mathrm{ml} 0.05 \% \text { solution }\end{array}$ & 14 in the ear vein & $5 / 5$ & 1. \\
\hline \multicolumn{4}{|l|}{ 2. $0.6 \mathrm{mg}$ sulpholipid and $6 \mathrm{mg}$} \\
\hline $\begin{array}{l}\text { lecithin in } 2 \mathrm{ml} 0.05 \% \text { solution } \\
\text { of methylated BSA } \\
\text { 3. } 6 \mathrm{mg} \text { sulpholinid in } 2 \mathrm{ml} 0.05 \%\end{array}$ & 14 in the ear vein & $5 / 5$ & $1: 3$ \\
\hline $\begin{array}{l}\text { 3. } 6 \mathrm{mg} \text { sulpholipid in } 2 \mathrm{ml} 0.05 \% \\
\text { solution of methylated BSA }\end{array}$ & 14 in the ear vein & $2 / 2$ & $1: 10$ \\
\hline 4. $6 \mathrm{mg}$ lecithin in $2 \mathrm{ml} 0.05 \%$ & & & \\
\hline solution of methylated BSA & 14 in the ear vein & $0 / 2$ & - \\
\hline $5.1 \mathrm{mg}$ methylated BSA in $2 \mathrm{ml}$ saline & 14 in the ear vein & $0 / 2$ & - \\
\hline
\end{tabular}

Table 1. Immunization schedule to obtain antisera against sulpholipid, lecithin and methylated bovine serum albumin.

after sodium periodate treatment ${ }^{15}$ for $16 \mathrm{~h}$ no reaction of the lipid with the antisera could be obtained. Therefore in this case the sulphoquinovose portion seems to be the reacting antigen determinant.

To examine the specificity of the sulpholipid antisera the mono- and digalactosyl-diacyl glycerol, lecithin and the anionic phosphatide phosphatidyl glycerol, also found in chloroplasts ${ }^{16}$, were tested. None of these lipids reacted with antisera against sulpholipid.

\section{Reaction of sulpholipid antisera with different chloroplast preparations}

For the immunological experiments the lamellar systems from Antirrhinum chloroplasts were isolated in sucrose solutions, thereby the soluble proteins were removed ${ }^{17}$. Suspensions of the lamellar systems were tested on slides or in small tubes. Sulpholipid antisera did not agglutinate with lamellar systems directly. This was expected since it is not possible to decrease the extend of agglutination of lamellar systems by antisera against lamellar systems by preincubation of the antisera with a mixture of acetone soluble lipids ${ }^{4}$ or with emulsions of purified sulpholipid at increasing concentrations (Table $2, \mathrm{C})$.

It is known that concentrated solutions for albumin have a hydrating effect on the outer layer of the membrane of the red blood cells ${ }^{18}$. This allows some antibodies to agglutinate the red blood cells

15 E. A. KabAT and M. M. Mayer, in: Experimental Immunochemistry, C. C. Thomas Ed., Springfield, Illinois, USA, 1961 , p. 542 .

16 A. T. James and B. W. Nichols, Nature [London] 210 , 372 [1966]; F. Haverkate and L. L. van DeEnen, Biochim. biophysica Acta [Amsterdam] 106, 78 [1965]. in this solution, but not in saline. Therefore the lamellar systems were suspended in a solution of $20 \%$ albumin and tested with sulpholipid antisera, but no agglutination was noted.

A possible interpretation of this finding might be that the sulpholipid is solated inside the thylakoid membrane and the determinant group would not be accessible for the antibodies. Another possible explanation might be that a reaction of the antibodies with the sulpholipid takes place, but no agglutination of the particles is to be seen, because the reacting determinant of the sulpholipid is located in depressions in the surface of the lamellar systems. After treatment with EDTA ${ }^{19}$ lamellar systems were also not agglutinated by sulpholipid antisera directly. An analogous experiment with ferredoxin$\mathrm{NADP}^{\oplus}$ reductase antisera ${ }^{3,4}$ were positive, i.e. lamellar systems treated with EDTA were agglutinated directly.

Next, agglutination inhibition experiments were carried out. As seen in Table 2 an antiserum against lamellar systems, which reacted with a sulpholipid emulsion down to a dilution of $1: 24$, did not react with sulpholipid emulsions, when it was absorbed with a suspension of $15 \mathrm{mg}$ lamellar systems $/ \mathrm{ml}$ or more, when equal volumes of the undiluted serum and the antigen suspension were mixed. Sulpholipid antiserum, which reacted with a sulpholipid emulsion down to a dilution of $1: 10$, was completely absorbed by adding equal volumes of a suspension

17 H. Nickel, Flora Abt. A 159, 233 [1968].

$18 \mathrm{H}$. J. Pettenkofer, in: Blutgruppenserologie, Beiheft zu den Laboratoriums-Blättern der Behring-Werke, 1961, Heft 5.

19 A. T. Jagendorf and M. Smith, Plant Physiol. 37, 135 [1962]: M. Avron, Biochim. biophysica Acta [Amsterdam] 77, 699 [1963]. 


\begin{tabular}{|c|c|c|c|c|c|c|}
\hline \multirow[t]{2}{*}{$\begin{array}{l}\text { concentration } \\
\text { of the antigens } \\
\text { for the absorption }\end{array}$} & \multicolumn{2}{|c|}{$\begin{array}{l}\text { a) absorption with lamellar } \\
\text { systems }\end{array}$} & \multicolumn{2}{|c|}{$\begin{array}{l}\text { b) absorption with ultrasonically } \\
\text { treated lamellar systems }\end{array}$} & \multicolumn{2}{|c|}{$\begin{array}{l}\text { c) absorption with } \\
\text { sulpholipid }\end{array}$} \\
\hline & $\begin{array}{l}\text { supernat } \\
\text { lamellar } \\
\text { systems }\end{array}$ & $\begin{array}{l}\text { reacts with } \\
\text { sulpholipid }\end{array}$ & $\begin{array}{l}\text { supernat } \\
\text { lamellar } \\
\text { systems }\end{array}$ & $\begin{array}{l}\text { acts with } \\
\text { sulpholipid }\end{array}$ & $\begin{array}{l}\text { supernat } \\
\text { lamellar } \\
\text { systems }\end{array}$ & $\begin{array}{l}\text { reacts with } \\
\text { sulpholipid }\end{array}$ \\
\hline $2.5 \mathrm{mg} / \mathrm{ml}$ & ++++ & ++++ & ++++ & ++++ & ++++ & ++++ \\
\hline $5.0 \mathrm{mg} / \mathrm{ml}$ & ++++ & $+++t$ & ++++ & ++ & ++++ & +++ \\
\hline $10.0 \mathrm{mg} / \mathrm{ml}$ & +++ & ++ & +++ & \pm & ++++ & ++ \\
\hline $15.0 \mathrm{mg} / \mathrm{ml}$ & +++ & \pm & ++ & - & ++++ & + \\
\hline $20.0 \mathrm{mg} / \mathrm{ml}$ & ++ & - & - & - & ++++ & - \\
\hline $30.0 \mathrm{mg} / \mathrm{ml}$ & + & - & - & - & ++++ & - \\
\hline $35.0 \mathrm{mg} / \mathrm{ml}$ & - & - & - & - & ++++ & - \\
\hline
\end{tabular}

Table 2. Agglutination inhibition experiments. $0.2 \mathrm{ml}$ undiluted antiserum against lamellar systems with a titer against lamellar systems of 1 : 2048 and a titer against sulpholipid of $1: 24$ was mixed wih $0.2 \mathrm{ml}$ of suspensions with increasing concentrations of lamellar systems, ultrasonically treated lamellar systems and sulpholipid emulsions $(2.5$ to $35 \mathrm{mg} / \mathrm{ml}$ saline $)$. After $2 \mathrm{~h}$ at $20^{\circ}$ the reaction mixtures were centrifuged $(5 \mathrm{~min}$ at $13000 \mathrm{~g}$ ). The supernatants were tested with a suspension of lamellar systems $(1.5 \mathrm{mg} / \mathrm{ml}$ in saline) and with sulpholipid emulsions $(1 \mathrm{mg} / \mathrm{ml}$ in saline), using the slide test.

of $10 \mathrm{mg}$ lamellar systems $/ \mathrm{ml}$ or more. When the sera were absorbed with ultrasonically treated lamel. lar systems, $10 \mathrm{mg} / \mathrm{ml}$ was enough for the antiserum against lamellar systems and $5 \mathrm{mg} / \mathrm{ml}$ for the sulpholipid antiserum to absorb completely the antibodies against sulpholipid. Apparently, after ultrasonic treatment more determinants are exposed which then react with the sulpholipid antibodies.

These experiments showed that the determinant groups of the sulpholipid itself must be accessible for antibodies on the surface of the thylakoid stacks. Excluded is the unspecific reaction of sulpholipid antibodies with the surface of the lamellar systems ${ }^{2-} .4$ But as written before the lamellar systems were not agglutinated by the sulpholipid antisera directly. The easiest way to explain this apparent contradiction is to suggest that the sulpholipid is located in depressions of the surface of the isolated particles as mentioned above. To test this hypothesis, experiments were carried out after the experimental design of mixed antigen agglutination after UHLENBRUCK ${ }^{13}$ and the $\mathrm{C}$ o o m b s - test ${ }^{14}$ (Table 3 ). Suspensions of lamellar systems were mixed on slides with a sulpholipid antiserum, and after $30 \mathrm{sec}$ an emulsion of sulpholipid or an antiserum against rabbit- $\gamma$-globulin was added. In both cases lamellar systems were agglutinated indirectly in the second step of the reaction. From the control experiments listed above it is clear that the reaction of sulpholipid antibodies with the lamellar systems in the first step of the reaction is specific. Beside this, a positive reaction only could be achieved in the second step as an indirect agglutination, when the three components of the reaction were mixed in proper amounts in the right order (Table 3 ), and if the time for the first step of the reaction was not too short. These phenomena are discussed in earlier publications ${ }^{2-4}$. Therefore lamellar systems were not unspecifically coprecipitated with the agglutinates of the sulpholipid emulsions and sulpholipid antibodies, and they were not unspecifically coprecipitated with the sulpholipid antibodies and other $\gamma$-globulins of the rabbit blood sera by the $\gamma$-globulin antisera added in the second step. But sulpholipid antibodies reacted with determinants of sulpholipid molecules in the surface of the isolated particles.

Washing experiments gave the same result. Lamellar systems isolated in sucrose solutions were incubated with sulpholipid antisera, and all antibodies not bound to the surface of the particles were washed off with saline. Nevertheless the incubated lamellar systems were agglutinated indirectly by addition of an emulsion of sulpholipid or an antiserum against rabbit- $\gamma$-globulin.

Because it is not known to what extent the lamellar systems isolated in sucrose solutions are still surrounded by the chloroplast envelope, this structure could be the reason for the described agglutination behaviour of the particles with sulpholipid antisera. Thus the result of the indirect agglutinations would only allow some conclusions about the location of the sulpholipid in the thylakoid, but not about the surface structure of the lamellar systems. Therefore broken chloroplasts from Antirrhinum leaves were isolated according to the procedure of Allen ${ }^{20}$ et al., and tested. These particles were agglutinated directly by sulpholipid antisera in con-

20 M. B. Allen, F. R. Whatley, and D. I. Arnon, Biochim. biophysica Acta [Amsterdam] 32, 32 [1959]. 


\begin{tabular}{|c|c|c|c|c|c|}
\hline component No. 1 & component No. 2 & firs & t reaction & component No. 3 & second reaction \\
\hline 1. lamellar systems & sulpholipid antiserum & & \pm & saline & \pm \\
\hline 2. lamellar systems & sulpholipid antiserum & & \pm & sulpholipid & green agglutinates \\
\hline 3. sulpholipid antiserum & sulpholipid & white & agglutinates & lamellar systems & $\begin{array}{l}\text { lamellar systems remain } \\
\text { homogeneously distributed }\end{array}$ \\
\hline 4. lamellar systems & sulpholipid & & - & $\begin{array}{l}\text { sulpholipid } \\
\text { antiserum }\end{array}$ & green and white agglutinates \\
\hline 5. lamellar systems & sulpholipid antiserum & & \pm & standard serum & \pm \\
\hline 6. lamellar systems & sulpholipid antiserum & & \pm & $\begin{array}{l}\text { rabbit- } \gamma \text {-globulin } \\
\text { antiserum }\end{array}$ & green agglutinates \\
\hline 7. sulpholipid antiserum & $\begin{array}{l}\text { rabbit- } \gamma \text {-globulin } \\
\text { antiserum }\end{array}$ & white & precipitates & lamellar systems & $\begin{array}{l}\text { lamellar systems remain } \\
\text { homogeneously distributed }\end{array}$ \\
\hline 8. lamellar systems & $\begin{array}{l}\text { rabbit- } \gamma \text {-globulin } \\
\text { antiserum }\end{array}$ & & - & $\begin{array}{l}\text { sulpholipid } \\
\text { antiserum }\end{array}$ & only white precipitates \\
\hline 9. lamellar systems & sulpholipid antiserum & & \pm & methylated BSA & \pm \\
\hline 10. lamellar systems & $\begin{array}{l}\text { methylated BSA } \\
\text { antiserum }\end{array}$ & & - & methylated BSA & only white precipitates \\
\hline 11. lamellar systems & $\begin{array}{l}\text { methylated BSA } \\
\text { antiserum }\end{array}$ & & - & sulpholipid & - \\
\hline 12. lamellar systems & $\begin{array}{l}\text { methylated BSA } \\
\text { antiserum }\end{array}$ & & - & $\begin{array}{l}\text { rabbit- } \gamma \text {-globulin } \\
\text { antiserum }\end{array}$ & only white precipitates \\
\hline $\begin{array}{l}\text { 13. lamellar systems after } \\
\text { ultrasonic treatment }\end{array}$ & sulpholipid antiserum & green & agglutinates & & \\
\hline 14. broken chloroplasts & sulpholipid antiserum & green & agglutinates & & \\
\hline 15. lamellar systems & $\begin{array}{l}\text { lamellar systems } \\
\text { antiserum }\end{array}$ & green & agglutinates & & \\
\hline
\end{tabular}

Table 3. Indirect and direct agglutination experiments and controls (slide tests). Lamellar systems were isolated in sucrose solutions, broken chloroplasts in $\mathrm{NaCl}$ solutions and suspended, and the pure sulpholipid suspended and emulsified as described under experiments and methods. Undiluted sera were used, and the concentration of antigens were: lamellar systems $1.5 \mathrm{mg} / \mathrm{ml}$; lamellar systems after ultrasonic treatment $1 \mathrm{mg} / \mathrm{ml}$; broken chloroplasts $1.5 \mathrm{mg} / \mathrm{ml}$; sulpholipid $3 \mathrm{mg} / \mathrm{ml}$, and methylated BSA $1 \mathrm{mg} / \mathrm{ml}$; all in saline.

trast to the antisera against ferredoxin-NADP ${ }^{\oplus}$ reductase, which agglutinated those particles only indirectly. According to electron microscope studies ${ }^{21}$ broken chloroplasts consist of thylakoid stacks which are not surrounded by the chloroplast envelope. However, from these investigations it cannot be excluded with certainty, that there are some thylakoids disrupted in the preparation and therefore the inside surfaces exposed and accessible to antibodies in the suspension.

Further experiments were carried out with lamellar systems isolated in sucrose solutions and disrupted. Both treatments with the high pressure in a French press ${ }^{22}$ and ultrasonic treatment led to a suspension of particles, which was homogeneous in the light microscope and could be agglutinated directly by sulpholipid antisera.

All agglutination experiments were carried out with sulpholipid antisera obtained by injection of

21 A. Kahn and D. von Wettstein, J. Ultrastr. Res. 5, 557 [1961]; G. JAKOBI and E. PERner, Flora 150, 209 [1961]; E. Perner, Planta 66, 44 [1965]; T. E. Weier, C. R. Stocking, C. E. Bracker, and E. B. Risley, Amer. J. Bot. 52. 339 [1965]. sulpholipid adsorbed to methylated BSA and with antisera obtained by injection of sulpholipid absorbed together with lecithin to methylated BSA. Equal results were obtained with both antisera.

\section{Discussion}

Chloroplasts isolated in sucrose solutions loose most of their stroma proteins when repeatedly washed with water, while retaining a morphologicaly intact lamellar system ${ }^{17}$. These lamellar systems are not agglutinated by antibodies against sulpho. lipid but the antibodies will be adsorbed specifically. The lamellar systems incubated with the antibodies, agglutinate when postincubated with the antigen or the rabbit- $\gamma$-globulin antiserum. This indicates that determinants of sulpholipid are accessible for the antibodies, but do not permit a direct agglutination. Such a behaviour can be explained if there are pro-

22 K. L. Simpson, A. W. Wilson, E. Burton, T. O. M. Nakajama, and C. O. Chichester, J. of Bacteriol. 86, 1126 [1963]. 
trusions or depressions on the surface of the thylakoids and the antigens are present in these deepenings.

In our chloroplast lamellar system preparations we cannot exclude the presence of the outer membrane of the chloroplast, even though they loose most of their stroma. The stroma could be lost by perforations of the outer membrane. The pieces of the membrane residing on the surface of the lamellar system can also hinder the direct agglutination. But considering the thickness of the outer membrane it is very unlikely that a simple mixed antigen reaction would suffice for an indirect agglutination of the lamellar system.

The indirect agglutination of the lamellar system with the antibodies against ferredoxin-NADP ${ }^{\oplus}$ reductase $^{3}$ has been shown to be due to protrusions present on the surface of the lamellar system. These protrusions have been suggested to be the coupling factor molecules since they are washed away by EDTA treatment ${ }^{19,23}$.

In the case of sulpholipid antibodies the lamellar systems even after EDTA treatment show no direct agglutination. It is reasonable to assume that the sulpholipid molecules are located at the bottom of depressions present on the thylakoid surface. Isolated lamellar systems after disruption with ultrasonication or french press result in particles which exhibit a direct agglutination with the sulpholipid antibodies. A preparation of broken chloroplasts ${ }^{20}$ also agglutinate when incubated with sulpholipid

23 V. K. Vambutas and E. Racker, J. Biol. Chem. 240, 2660 [1965].

24 W. MEnke, unpublished. antisera. By mechanical disruption the inside of thylakoids will be accessible for antibodies. In such preparations a direct agglutination is observed and it can therefore be assumed that sulpholipid molecules are also located on the inner side of the thylakoid membrane. However we cannot exclude with certainty that the natural distribution of the sulpholipid molecules are disturbed or the outer surface of the thylakoids is changed during mechanical disruption of chloroplasts. There is no experimental evidence to show disorganization of sulpholipid molecules or an alteration of the outer thylakoids surface during such a treatment. On the other hand electronen microscopic observations of mechanical disrupted plastids, which have capacity of a direct agglutination, contain fragments of broken thylakoids ${ }^{24}$.

Thus it is concluded, that the sulpholipid is located inside the thylakoids, but at least some sulphoquinovosyl residue are orientated against the outer protein layer and accessible to antibodies through some kind of spaces between the protein. Therefore the result with sulpholipid antibodies are not in contradiction to the thylakoid model proposed by Menke and Kreutz ${ }^{25}$.

We express our sincere thanks to Prof. Dr. W. MENke for his support and for several helpful discussions. We thank Miss Dr. D. VAN WYK for useful hints, and Miss P. M. Sessler for her skillful technical assistance. The investigations were sponsored by the Deutsche Forschungsgemeinschaft.

25 W. Kreutz and W. Menke, Z. Naturforsch. 17 b, 675 [1962]; W. KReutz, Z. Naturforsch. 18 b, 1098 [1963]; and 19 b, 441 [1964] ; W. Menke, in: Photosynthesis Mechanisms in green Plants, Publ. 1145, Natl. Acad. Sciences, Natl. Res. Council 1963, p. 537; W. Menke, in: Biochemistry of chloroplasts, Vol. I, (ed. T. W. GoodwiN) Acad. Press, London and New York 1967, p. 3. 